\title{
High-voltage electrical stimulation improves nerve regeneration after sciatic crush injury
}

\author{
Estimulação elétrica de alta voltagem favorece a regeneração nervosa após \\ compressão do nervo isquiático
}

Rosana M. Teodori, Andréia M. Silva, Meiricris T. Silva, Larissa S. Oliveira, Maria L. O. Polacow, Elaine C. O. Guirro

\begin{abstract}
Background: Peripheral nerve injury causes prolonged functional limitation being a clinical challenge to identify resources that accelerates its recovery. Objectives: To investigate the effect of high-voltage electrical stimulation (HVES) on the morphometric and functional characteristics of the regenerated nerve after crush injury in rats. Methods: Twenty Wistar rats were randomly allocated into 4 groups: Control (CON) - without injury and without HVES; Denervated (D) - sciatic nerve crush only; Denervated + HVES - sciatic nerve crush and HVES; SHAM - without injury but HVES. The HVES and SHAM groups were stimulated (100 Hz; minimum voltage of $100 \mathrm{~V}, 20 \mu \mathrm{s}, 100 \mu$ s interpulse interval) for $30 \mathrm{~min} /$ day, 5 days/week. The sciatic functional index (SFI) was evaluated before the injury and at the $7^{\text {th }}, 14^{\text {th }}$ and $21^{\text {st }}$ postoperatory (PO) days. Neural components and the area density of connective tissue, blood vessels and macrophages were analyzed. Results: Axonal diameter was higher on the HVES than on D group, reaching almost $80 \%$ above the control values after 21 days $(p<0.05)$. Fiber diameter and myelin sheath thickness were higher on the HVES than on D group $(p<0.05)$ reaching $96.5 \%$ and $100 \%$ of the control values, respectively. Functional recovery at the $14^{\text {th }} \mathrm{PO}$ day was better on group HVES. The macrophages and connective tissue area density was lower on the HVES group, while blood vessels number did not differ among groups. Conclusions: The HVES accelerated the functional recovery, potentiated the nerve fibers maturation and decreased macrophages and connective tissue area density, suggesting acceleration of neural repair.
\end{abstract}

Keywords: nerve crush; peripheral nerves; nerve regeneration; electric stimulation; sciatic nerve; physical therapy modalities.

\section{Resumo}

Contextualização: Lesões nervosas periféricas provocam limitação funcional prolongada, sendo um desafio para a clínica identificar recursos que acelerem sua recuperação. Objetivos: Investigar a influência da estimulação elétrica de alta voltagem (EEAV) sobre a morfologia e a função do nervo regenerado após esmagamento em ratos. Métodos: Vinte ratos Wistar foram divididos nos grupos: controle (CON)-sem lesão e sem EEAV; desnervado (D) - esmagamento do nervo isquiático; desnervado + EEAV (EEAV) - esmagamento do nervo e EEAV; SHAM - sem lesão, porém submetido à EEAV. Os grupos EEAV e SHAM foram estimulados (100 Hz, tensão mínima

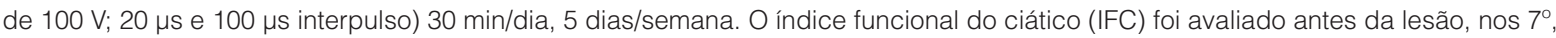
$14^{\circ}$ e $21^{\circ}$ dias pós-operatório (PO). Componentes neurais, densidade de área de tecido conjuntivo, de vasos sanguíneos e macrófagos foram analisados. Resultados: O diâmetro axonal foi maior no grupo EEAV que no grupo D, atingindo quase $80 \%$ dos valores-controle após 21 dias $(p<0,05)$. O diâmetro das fibras e espessura das bainhas de mielina foram maiores no grupo EEAV que no $D(p<0,05)$, alcançando $96,5 \%$ e $100 \%$ dos valores-controle, respectivamente. A recuperação funcional no $14^{\circ}$ dia PO foi melhor no grupo EEAV. A densidade de área de macrófagos e tecido conjuntivo foi menor no grupo EEAV, enquanto o número de vasos sanguíneos não diferiu entre os grupos. Conclusões: A EEAV acelerou a recuperação funcional, potencializou a maturação das fibras nervosas regeneradas e promoveu diminuição da densidade de área de macrófagos e tecido conjuntivo no nervo, sugerindo aceleração do reparo neural.

Palavras-chave: compressão nervosa; nervos periféricos; regeneração nervosa; estimulação elétrica; nervo isquiático; modalidades de fisioterapia.

Received: 08/09/2010 - Revised: 14/03/2011 - Accepted: 10/05/2011

Master's Program in Physical Therapy, Universidade Metodista de Piracicaba (UNIMEP), Piracicaba, SP, Brazil

Correspondence to: Rosana Macher Teodori, Universidade Metodista de Piracicaba, School of Health Sciences, Master's Program in Physical Therapy, Neuromuscular, Plasticity Laboratory, Rodovia do Açúcar, Km 156, Taquaral, CEP 13.400-911, Piracicaba, SP, Brazil, e-mail: rteodori@unimep.br 


\section{Introduction $: \because 8$}

Traumatic injury of peripheral nerves is common and results in significant functional deficits. After crush injuries, regeneration occurs spontaneously. In rats, no axons are found in the muscle ten days after injury because the muscle reinnervation begins two weeks after the injury ${ }^{1,2}$.

Poly-innervation is observed two days after the neuritis reach the muscle, given that fifteen days after nerve crush $25 \%$ of muscle fibers are poly-innervated. The increase of neuritis sprouting and growth, as well as the formation of synapses between 14 and 25 days after injury indicate that nerve impulses may be released to the muscle ${ }^{2}$. Around the $25^{\text {th }}$ day, muscle membrane rest potential, contraction force, sensitivity to acetylcholine, and acetylcholinesterase levels have returned to normal. The process that eliminates excessive synaptic contacts starts at this time and, around the $60^{\text {th }}$ day, muscle fibers become mono-innervated. The remaining nerve terminals are increased in size and after 90 days the postsynaptic cleft is almost completely occupied ${ }^{1}$.

However, at the end of the regeneration morphological alterations on regenerated axons remain. After section injuries, the nerve presents reduced axonal caliber and decreased myelin sheath thickness ${ }^{3}$. Even in crush injuries, nerve morphometric properties are not fully recovered ${ }^{4}$.

In humans, the most notable characteristic of denervation is muscular atrophy, which is determined by the reduction in quantity of actin and myosin myofilaments, and results in a decrease of fiber diameter and loss of muscle force ${ }^{5}$.

$\mathrm{Lu}$, Huang and Carlso $\mathrm{C}^{6}$ demonstrated the negative effects caused by an increase of intramuscular connective tissue after denervation, which alters muscle function by delaying nutrient exchange between muscle fibers and the capillary system, as well as interfering with axonal growth during reinnervation. Due to slow progress inherent to nerve recovery ${ }^{7}$ the structural conditions of a denervated muscle remain widely altered during nerve recovery in humans, which compromises the return to work. Since the maturation of regenerated nerve is essential for the nerve conduction speed and functional recovery, the main clinical challenge is to identify mechanisms to accelerate the nerve regeneration.

It is known that animal tissues are endowed with intrinsic electricity that is involved with fundamental physiological processes, such as nerve conduction and muscle contraction ${ }^{8}$. The complete motor function recovery after nerve injury requires the occurrence of morphological and physiological processes that determine the return of motoneurons electrical activity on the involved muscles?.

The use of muscle electrical stimulation after peripheral nerve injury for the prevention of progressive muscle atrophy, although there is weak evidence that, can be beneficial when applied under favorable conditions ${ }^{10}$. This fact reinforces the importance of controlled trials for the establishment of new treatment strategies to stimulate peripheral nerve regeneration.

High-voltage electrical stimulation (HVES) has gained acceptance in both experimental and clinical research ${ }^{11,12}$. Most studies that use HVES investigate its circulatory ${ }^{13}$ and regenerative properties on skin ulcers healing ${ }^{14}$.

The application of negative electric fields increases regeneration of the peripheral nerves in mammals ${ }^{15}$. However, there are no studies suggesting the effect of HVES on the peripheral nerve regeneration, which justifies the need for need for high quality studies that will permit a greater understanding of HVES and its role on this process, as well as will stimulate discussion of its use on the peripheral nerve injury treatment in humans. Thus, the hypothesis of the present study is that HVES can shorten the regeneration and maturation of injured nerves.

Therefore, the aim of this study was to investigate the influence of high-voltage electrical stimulation on the morphometric and functional characteristics of the regenerated nerve after crush injury in rats.

\section{Methods $: \because$.}

Twenty male Wistar rats $(210.80 \pm 10.79 \mathrm{~g})$ were randomly allocated into 4 groups ( $\mathrm{n}=5$ each): Control (CON) - animals without injury and without HVES; Denervated (D) - sciatic nerve crush; Denervated + HVES (HVES) - sciatic nerve crush and HVES; SHAM - without injury, but subjected to HVES (SHAM).

This study was approved by the Ethics Committee for Animal Experimentation of the UniversidadeFederal de São Carlos(CEEA/ UFSCar), São Carlos, SP, Brasil, protocol number 037/2008.

\section{Functional gait analysis: Sciatic Functional Index (SFI)}

For the functional gait assessment, a pathway of $8.2 \times 42 \mathrm{~cm}$ was covered with white paper and the animals were set to walk on it, with their hind paws marked with fingerprinting ink. This registration was performed prior to the crush injury, and at the $7^{\text {th }}, 14^{\text {th }}$ and $21^{\text {st }}$ post operatory (PO) days ${ }^{16}$. Distances between the extremity of the third finger and the calcaneous - Print Length (PL); between the first and fifth toes - Total Spreading (TS); and between the second and fourth toes - Intermediary Toes (ITS) were measured in the experimental and normal paws using a Mitutoyo $^{\mathrm{TM}}$ digital pachymeter with an accuracy of $0.01 \mathrm{~mm}$, according to the manufacturer's manual. The obtained values were used in the equation proposed by the same authors ${ }^{16}$. The results were expressed as functional loss, being that the value 0 (zero) representing normal function, and the value of -100 (minus one hundred) representing maximum disability. 


\section{Nerve injury}

The animals in D and HVES groups were submitted to a crush injury (performed surgically) on the left sciatic nerve. They received intramuscular anesthesia with Ketamine Chloride $(1.16 \mathrm{~g} / 10 \mathrm{~mL})$ and Xylazine Chloride $(2 \mathrm{~g} / 100 \mathrm{~mL})$ at a 3:2 ratio with doses of $0.09 \mathrm{~mL} / 100 \mathrm{~g}$ and $0.06 \mathrm{~mL} / 100 \mathrm{~g}$ of their body weight, respectively, additionally a digital trichotomy on their gluteal region was performed, bilaterally. The left sciatic nerve was crushed with a haemostatic forceps, $5 \mathrm{~mm}$ proximal to its branching point, by four 20 -second clamps with one second of interval between them ${ }^{17}$. The same researcher crushed all nerves.

Animals from the SHAM group had the sciatic nerve exposed and maintained intact. All animals were kept under vivarium conditions, subjected to a 12-hour photoperiodic cycle of light/dark, controlled temperatures $\left(23 \pm 2{ }^{\circ} \mathrm{C}\right)$, and had constant access to special food (Labina, Purina ${ }^{\mathrm{TM}}$ ) and water. In the first two days after surgery, the animals received $4 \mu \mathrm{L}$ of Sodic Dipirone $(500 \mathrm{mg} / \mathrm{mL}$ ) by oral administration, for analgesic effect, every 12 hours.

\section{High Voltage Electrical Stimulation (HVES)}

The Neurodyn High Volt - ANVISA 10360310008 IBRAMED ${ }^{\text {TM }}$ was used in this study. The calibration was performed with an oscilloscope Tektronix (TDS $\left.{ }^{\mathrm{TM}}\right) 210$, with a load of $1000 \Omega$, while the timer was calibrated using three stopwatches (Technos ${ }^{\mathrm{TM}}$ ).

The intervention on HVES and SHAM groups was performed under anesthesia (Ketamine Chloride and Xylazine Chloride $-0.045 \mathrm{~mL} / 100 \mathrm{~g}$ and $0.03 \mathrm{~mL} / 100 \mathrm{~g}$ of body weight, respectively) and was initiated 24 hours after the crush injury, with cathodic stimulation at the motor threshold, for $30 \mathrm{~min}$ utes $(100 \mathrm{~Hz}$; minimum voltage of $100 \mathrm{~V}, 20 \mu$ s and $100 \mu$ s interpulse interval), 5 days a week, during 21 days. A silicon-carbon active electrode $(2.0 \times 2.0 \mathrm{~cm})$ was placed over the surgical scar, while the dispersive electrode $(4.0 \times 4.0 \mathrm{~cm})$ was positioned parallel to the active, preserving a distance of $1 \mathrm{~cm}$ between them. Sterile gel was used on the skin shaved as a conductor.

\section{Data collection}

After 21 days, the animals were anesthetized by the same procedures as described for the nerve injury. The left sciatic nerve was fixed in situ at $4^{\circ} \mathrm{C}$ during 10 minutes, with modified Karnovsky fixative containing $1 \%$ of paraformaldehyde and $2 \%$ of glutaraldehyde in a sodium cacodylate buffer at $0.1 \mathrm{M}, \mathrm{pH}$ 7.3. Next, the nerve segment distal to the injury was removed and the animals were euthanized by cervical dislocation.
The sciatic nerve fragments were maintained in the same fixative solution for 24 hours and postfixed in osmium tetroxide at $1 \%$ in sodium cacodylate buffer at $0.1 \mathrm{M}, \mathrm{pH} 7.3$, for two hours, immersed in $5 \%$ uranyl during 24 hours for en bloc staining, dehydrated in increasing solutions (30\% to 100\%) of acetone and included in Araldite ${ }^{\mathrm{TM}} 502$ resin. Transversal section cuts $(1 \mu \mathrm{m})$ of the distal nerve obtained $5 \mathrm{~mm}$ far to the crush were stained with toluidine blue at $1 \%$ borax aqueous solution for observation in light microscopy. In the control group, the transversal section cuts were obtained from the same region as the experimental groups.

\section{Quantitative and morphometric analysis}

For these analysis the examiner was blinded. The number and diameter of axons and the diameter of nerve fibers were determined $^{3}$. In this study we used an image analysis system (Image-Pro Plus 6.2 - Media Cybernetics ${ }^{\mathrm{TM}}$ ). From these data, the myelin sheath thickness was calculated.

For the area density analysis of connective tissue, blood vessels and macrophages, five non-serial sections were selected, in which five fields with a 1000x magnification were randomly photographed using an Infinity Lite (Lumenera Corporation ${ }^{\mathrm{TM}}$ ) digital camera attached to an Olympus ${ }^{\mathrm{TM}}$ BX 41 light microscope, which was connected to an image analysis system (Image-Pro Plus 6.2 - Media Cybernetics ${ }^{\mathrm{TM}}$, with a 100x objective lens). Following, a planimetry by a point-counting system ${ }^{18}$ was used, in which a grid with 450 line intersections per field, totalizing 56.250 intersections per experimental group, was applied in order to obtain the percentage of area density.

\section{Statistical analysis}

The Shapiro-Wilk normality test and a One Way ANOVA, followed by the post-hoc Tukey test were used for the number and density of blood vessels, density of macrophages and connective tissue, axon number, nerve morphometry and functional analysis. One Way ANOVA followed by Tamhane's T2 test (between-group comparisons) was used to calculate axonal diameter. To analyze the SFI between-group differences, Two Way ANOVA, followed by post hoc LSD test were utilized. The significance level of $5 \%$ was considered for all analyses.

\section{Results $\because \because$.}

\section{Quantitative and morphometric analysis}

No differences on the axons number was observed in all groups. The axonal and fiber diameter, as well as the myelin 
sheath thickness, were higher on the HVES group than on the D group. These results are displayed in Table 1.

\section{Histological analysis}

Figure 1 presents the morphological characteristics of the normal sciatic nerve, with axons surrounded by myelin sheaths with thickness proportional to its diameter (CON). In the denervated group (D), the axons, as well as the myelinated nerve fibers, present decreased diameters and myelin sheaths thickness, with an evident increase of neural connective tissue. When the injured nerve was subjected to HVES, the recovery of their morphometric characteristics was observed. As expected, nerves that were not injured but received HVES (SHAM) presented morphological characteristics similar to normal nerves.

\section{Functional gait analysis}

As presented in Figure 2, among the four different groups, the most effective functional recovery was observed in the rats allocated to the HVES group at the $14^{\text {th }}$ PO day $(\mathrm{p}<0.05)$.

\section{Area density of blood vessels, macrophages and connective tissue and blood vessels number}

Considering that the morphometric analysis revealed no differences between the CON and SHAM groups, these parameters, as well as the number of blood vessels, were investigated only on the CON, D and HVES groups.

No between-group differences in the area density of blood vessels were observed ( $p>0.05)$. Macrophages and connective tissue area densities were higher on $\mathrm{D}$ than on $\mathrm{CON}$ group

Table 1. Mean $\pm S D$ of quantitative and morphometric analysis on groups: Control (CON); Denervated (D); Denervated and High-voltage Electrical Stimulation (HVES); Without injury but High-voltage Electrical Stimulation (SHAM).

\begin{tabular}{lcccc}
\hline & CON & D & HVES & SHAM \\
\hline Axons Number & $9161.60 \pm 1394.14$ & $11140.60 \pm 1152.53$ & $9780.60 \pm 2061.95$ & $10078.00 \pm 2261.94$ \\
\hline Axons Diameter $(\mu \mathrm{m})$ & $6.73 \pm 0.38$ & $3.53 \pm 0.43^{*}$ & $5.38 \pm 0.34^{\# *}$ & $6.43 \pm 1.16^{*}$ \\
\hline Fibers Diameter $(\mu \mathrm{m})$ & $11.45 \pm 0.49$ & $6.66 \pm 0.67^{*}$ & $11.05 \pm 0.59^{*}$ & $11.48 \pm 1.21^{*}$ \\
\hline Myelin Sheath Thickness $(\mu \mathrm{m})$ & $1.14 \pm 0.11$ & $0.75 \pm 0.06^{*}$ & $1.24 \pm 0.11^{*}$ & $1.21 \pm 0.05^{*}$ \\
\hline
\end{tabular}

(\#) Differ from CON group; ( $\left.{ }^{*}\right)$ Differ from D group $(p<0.05)$
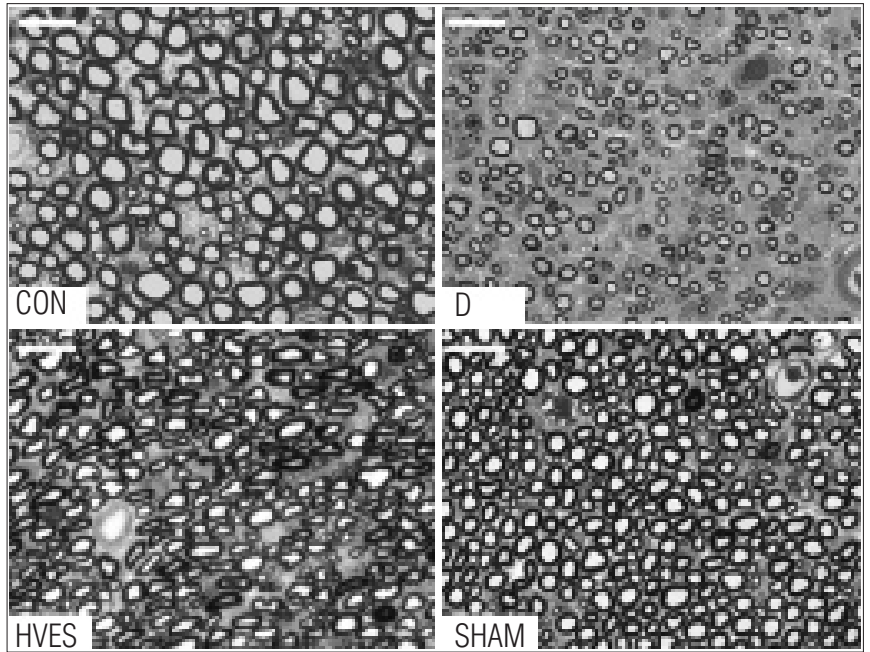

Figure 1. Transverse section of sciatic nerve on groups: Control (CON); Denervated (D); Denervated and High Volt Electrical Stimulation (HVES); and SHAM (SHAM). Note the differences in the axon diameter and myelin sheath thickness, as well as the neural connective tissue area. Toluidine Blue stain. Bar=20 $\mu \mathrm{m}$.

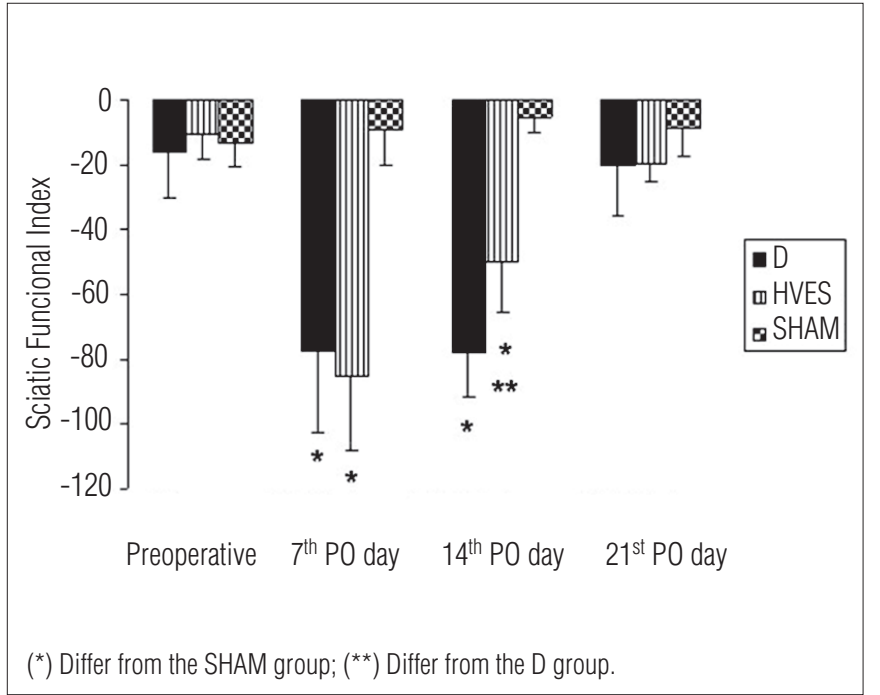

Figure 2. Between-Groups comparison of Functional Sciatic Index (FSI) on groups: Denervated (D); Denervated and High Volt Electrical Stimulation (HVES); Without injury but High Volt Electrical Stimulation (SHAM) in different moments. 
Table 2. Mean $\pm S D$ of neural blood vessels number and area density; macrophages and connective tissue area density on groups: Control (CON); Denervated (D); Denervated and High-voltage Electrical Stimulation (HVES).

\begin{tabular}{lccc}
\hline & CON & D & HVES \\
\hline Blood Vessels Number & $1.4 \pm 0.24$ & $1.62 \pm 0.45$ & $2.0 \pm 1.15$ \\
\hline Blood Vessels Area Density (\%) & $2.69 \pm 1.16$ & $2.64 \pm 0.39$ & $2.12 \pm 1.24$ \\
\hline Macrophages Area Density (\%) & $6.96 \pm 2.81$ & $19.99 \pm 10.75^{*}$ & $5.10 \pm 2.39$ * \\
\hline Connective Tissue Area Density (\%) & $36.44 \pm 7.65$ & $57.69 \pm 10.51^{*}$ & $38.86 \pm 9.54^{*}$ \\
\hline
\end{tabular}

(\#) Differ from CON group; ( $\left.{ }^{*}\right)$ Differ from D group $(p<0.05)$.

$(\mathrm{p}<0.05)$. The HVES reduced the macrophages and connective tissue area densities after nerve crush injury $(\mathrm{p}<0.01)$ with estimates being very similar to the control group.

There was no between-group difference ( $p>0.05)$ for the number of blood vessels in the nerve (Table 2).

\section{Discussion $: \because$.}

In a pilot study, a group of 5 Wistar rats was submitted to the injury method described and had the nerve segment distal collected and histologically analyzed after 6 days. Considering that the myelin sheaths engage in an intense deterioration process 36 to 48 hours after injury ${ }^{19}$ the observation of either the presence or the absence of intact nerve fibers would allow for a demonstration of the efficacy of the chosen method. An absence of intact nerve fibers was observed, as well as extensive axonal deterioration, making this nervous injury method valid for evaluative studies of different resources to be used in the stimulation of peripheral nerve regeneration.

The influence of low frequency biphasic currents over denervated muscle has been established ${ }^{20}$. Oliveira et al. ${ }^{21}$ showed that low frequency electrical stimulation on rat denervated soleus muscle favored axonal sprouting after nerve crush injury, since the axon number doubled after 21 days, which was justified by an increase in endoneural blood flow with a consequent supply increase of the trophic substances needed for nerve regeneration.

However, despite being a therapeutic resource used in various clinical treatments, this is the first report on the effects of the High Voltage Electrical Stimulation (HVES) after peripheral nerve injury in rats. The clinical advantage of HVES is that the stimulation is confortable and affects sensory, motor and nociceptive nerve fibers. The physical parameters involved in this current allow for several therapeutic effects, such as pain and edema control ${ }^{22}$, as well as acceleration of tissue repair ${ }^{23,24}$.
Houghton et al. ${ }^{25}$ demonstrated the HVES effectiveness on human's chronic skin ulcers regeneration. Subjects treated with HVES presented $44.3 \%$ reduction in ulcer area after 4 weeks, while those that received conventional treatment improved only $16 \%$.HVES can influence blood flow, but this effect depends on the physical parameters used as well as the stimulation site ${ }^{23}$. Mohr, Akers and Wessman ${ }^{26}$ observed significant increase on blood flow velocity in the rat hind limb during and after HVES application with a cathodic stimulation.

In this study we used the cathodic stimulation, however the blood flow velocity was not assessed, but the number and area density of blood vessels, where no difference was observed when the HVES was applied. This suggests that this resource only influence the velocity of blood flow, apparently not promoting angiogenesis.

This study used HVES at the motor threshold because a rhythmic muscle contraction is required to increase arterial blood flow to the stimulated area. However, it seems necessary to investigate the characteristics of blood flow in the area where stimulation was applied, since the quantitative analysis of blood vessels failed to identify any influence of HVES. It is possible that the use of different parameters may contribute to understanding the effects of HVES on blood flow in regenerated nerves.

After two to four weeks of the sciatic nerve crush in rats, the axon number in the distal segment tends to increase by two-fold ${ }^{7}$ due to axonal sprouting. In this study, both denervated groups showed number of axons similar to control group, showing that HVES did not influence the number of regenerated fibers.

The HVES crosses the skin and produces negligible thermal and electrochemical effect, which allows for a greater current density to reach the target tissues, besides producing effects on vascular system, since the rhythmic muscular contraction/ relaxation increases blood flow on the muscle and neighboring tissues $^{27}$. 
It is possible that the cathodic stimulation on motor threshold applied at injured peripheral nerve has promoted a transient effect on blood flow to connective tissues surrounding the nerve, in this sense favoring the uptake of nutrients and neurotrophic factors essential to the nerve's morphological and physiological restoration, without changing the area density and the number of blood vessels, since these morphometric characteristics refer to the nerve analyzed 24 hours after the end of stimulation.

The results of the SHAM group demonstrated that the HVES application on normal nerve does not influence its quantitative and morphometric characteristics, highlighting the effect of HVES on the maturation of regenerated nerve fibers.

In this study, all morphometric parameters were completely recovered on the HVES group, with the exception of the axon diameter, since it did not reach control values after 21 days of injury. Considering that the nerve maturation is only completed when it is reconnected to the muscle and when the synaptic elimination occurs, which happens only around the $60^{\text {th }}$ day after crush injuries ${ }^{1,2}$ it is possible to suggest that HVES speed axonal maturation, once that these results were observed only 21 days after injury.

The HVES increased myelin sheath thickness in comparison to group D, which was proportional to axon diameter and automatically reflected on the nerve fibers diameter. These results exceeded the expectations of morphological recovery of injured nerve fibers, because, according to Schröder ${ }^{4}$, after crush injuries, the axons diameter can reach control values after 6 months, but the myelin sheath thickness reaches only $79 \%$ of normal values after 1 year. Mira ${ }^{28}$ identified the presence of regenerated nerve fibers after rat sciatic nerve crush between the $10^{\text {th }}$ and $15^{\text {th }}$ day, however, the variation of fiber diameters remained the same after two years of injury. In the present study, the diameter of regenerated axons after HVES treatment reached $79.9 \%$ of control values, while the nerve fibers diameter reached $96.5 \%$ and the myelin sheath thickness reaches $100 \%$ of the control values. These results demonstrate the benefits of HVES on the maturation of regenerated nerves after crush, as well as the earliness with which this occurred after its application, emphasizing the importance of future studies to demonstrate its role in transection nerve injury.

These results are reinforced when the morphometric data of other nerve elements are examined, such as the connective tissue. The macrophages, responsible for cell debris phagocytosis, presented the highest area density in $\mathrm{D}$ group at the $21^{\text {st }}$ day. In the HVES group, there was significant reduction of these cells, demonstrating a more advanced stage of regenerated tissue maturation. Probably, HVES stimulated the macrophages migration to the injury site because according to Orida and Feldman ${ }^{29}$ the macrophages tend to migrate toward the anode.

In this study, there was no influence of HVES on normal nerve function. On the denervated groups, the functional behavior followed the evidence already mentioned by Carmignoto et al. ${ }^{1}$ and Gorio et al. ${ }^{2}$, where complete function loss was observed between the $7^{\text {th }}$ and the $14^{\text {th }}$ day, and recovery at the $21^{\text {st }}$ PO day, when the muscle is almost completely re-innervated.

The between-group analysis showed that all groups presented normal function at the preoperatory period, whereas at the $7^{\text {th }}$ PO day, denervated groups showed significant function reduction. At the $14^{\text {th }} \mathrm{PO}$ day, these values remained close to -100 in D group, while there was significant functional recovery on the HVES group at the same time period. This fact demonstrates the HVES effectiveness in accelerating recovery, not only regarding the morphological characteristics of regenerated nerve, but also the restoration of muscles control by inferior motoneurons. At the $21^{\text {st }} \mathrm{PO}$ day, the two denervated groups recovered their function with no difference between HVES and D groups being observed.

These results suggest that the HVES use accelerated muscle reinnervation. Consequently, the acetylcholine release on the neuromuscular junction would be occurring precociously because, according to Gorio et al. ${ }^{2}$, after 15 days of nerve crush in rats, $25 \%$ of muscle fibers are reinnervated. It was observed in D group that at the $14^{\text {th }} \mathrm{PO}$ day there was no functional recovery, probably due to the fact that only one a fourth of muscle fibers were reinnervated, which would not reflect as improved function. However, on the HVES group, SFI values suggest that a larger number of muscle fibers were reinnervated, resulting in better contraction quality and improvement of function.

Despite the fact that the SFI results show that at the $21^{\text {st }}$ PO day all groups reached the normality values, once nerve regeneration and functional recovery occur spontaneously after crush injury ${ }^{7}$ is evident the acceleration of functional recovery in the HVES group, reinforcing the need to investigate the functional parameters on nerve section injuries.

It should be highlighted the importance of early functional recovery when considering the effects of denervation to the muscle. After denervation, muscle atrophy rapidly occurs, due to the loss of myofibrillar protein components that represent $60 \%$ of muscle proteins ${ }^{30}$, since contractile activity is important for the maintenance of the muscle fiber's cross-sectional area $^{10}$. Denervation reduces the muscle fiber cross-sectional area, increases the area density of the intramuscular connective tissue, undermining the muscle reinnervation, limiting the 
interaction of nerve terminals with acetylcholine receptors at the neuromuscular junction ${ }^{31}$.

The HVES application accelerated nerve regeneration, propitiating to the muscle the possibility of an earlier voluntary activity recovery, thereby preventing the development of denervation deleterious effects.

\section{Concluding remarks $: \because$.}

It is concluded that HVES accelerated the regenerated nerve fibers maturation after crush injury, as well as functional recovery. Our results suggest that the utilization of HVES could contribute to a more favorable regeneration of peripheral nerve injury by aiding in a premature functional recovery, reducing treatment costs, and in providing a faster reintegration of the subjects to his or her labor activity.

Additional studies may contribute to specify the time of nerve regeneration initiation after HVES application, as well as to promote the use of this resource on human peripheral nerve injury treatment.

\section{Acknowledgments $: \therefore$.}

To the Conselho Nacional de Desenvolvimento Cientifico e Tecnológico (CNPq), for the research productivity grant (Process $\left.n^{\circ} 307041 / 2008-5\right)$.

\section{References $: \because$.}

1. Carmignoto G, Finesso M, Siliprandi R, Gorio A. Muscle reinnervation - I. Restoration of transmitter release mechanisms. Neuroscience. 1983;8(3):392-401.

2. Gorio A, Carmignoto G, Finesso M, Polato P, Nunzi MG. Muscle reinnervation - II. Sprouting, synapse formation and repression. Neuroscience. 1983;8(3):406-16.

3. Santo Neto H, Pertille A, Teodori RM, Somazz MC, Marques MJ. Primary nerve repair by muscle autografts prepared with local anesthetic. Microsurgery. 2004;24(3):188-93.

4. Schröder JM. Altered ratio between axon diameter and myelin sheath thickness in regenerated nerve fibers. Brain Res. 1972;45(1):49-65.

5. Sheffler $L R$, Chae J. Neuromuscular electrical stimulation in neurorehabilitation. Muscle Nerve. 2007;35(5):562-90

6. Lu DX, Huang SK, Carlson BM. Electron microscopic study of long-term denervated rat skeletal muscle. Anat Rec. 1997;248(3):355-65.

7. Fawcett JW, Keynes RJ. Peripheral nerve regeneration. Annu Rev Neurosci. 1990;13:43-60.

8. Hess D, El Manira A. Characterization of a high-voltage-activated $I_{A}$ current with a role in spike timing and locomotor pattern generation. Proc Natl Acad Sci U S A. 2001;98(9):5270-81.

9. English AW, Schwartz G, Meador W, Sabatier MJ, Mulligan A. Electrical stimulation promotes peripheral axon regeneration by enhanced neuronal neurotrophin signaling. Dev Neurobiol. 2007;67(2):158-72

10. Dow DE, Cederna PS, Hassett CA, Kostrominova TY, Faulkner JA, Dennis RG. Number of contractions to maintain mass and force of a denervated rat muscle. Muscle Nerve. 2004;30(1):77-86.

11. Mendel FC, Wylegala JA, Fish DR. Influence of high voltage pulsed current on edema formation following impact injury in rats. Phys Ther. 1992;72(9):668-73

12. Garcia LB, Guirro ECO. Efeitos da estimulação de alta voltage no linfedema pós-mastectomia. Rev Bras Fisioter. 2005;9(2):243-8

13. Taylor K, Mendel FC, Fish DR, Hard R, Burton HW. Effect of high-voltage pulsed current and alternating current on macromolecular leakage in hamster cheek pouch microcirculation. Phys Ther. 1997;77(12):1729-40

14. Davini R, Nunes CV, Guirro ECO, Guirro RRJ. Estimulação elétrica de alta voltage: uma opção de tratamento. Rev Bras Fisioter. 2005;9(3):249-56.

15. Román GC, Strahlendorf HK, Coates PW, Rowley BA. Stimulation of sciatic nerve regeneration in the adult rat by low-intensity electric current. Exp Neurol. 1987;98(2):222-32.

16. Bain JR, Mackinnon SE, Hunter DA. Functional evaluation of complete sciatic peroneal, and posterior tibial nerve lesions in the rat. Plast Reconstr Surg. 1989;83(1):129-38.

17. Lima SC, Caierão QM, Peviani SM, Russo TL, Somazz MC, Salvini TF, et al. Muscle and nerve responses after different intervals of electrical stimulation sessions on denervated rat muscle. Am J Phys Med Rehabil. 2009;88(2):126-35.

18. Mathieu 0, Cruz-Orive LM, Hoppeler $\mathrm{H}$, Weibel ER. Measuring error and sampling variation in stereology: comparison of the efficiency of various methods for planar image analysis. J Microsc. 1981;121(Pt 1):75-88.

19. Dubový P. Schwann cells and endoneurial extracellular matrix molecules as potential cues for sorting of regenerated axons: a review. Anat Sci Int. 2004;79(4):198-208.

20. Caierão QM, Betini J, Teodori RM, Minamoto VB. The effect of time interval between electrica stimulation on the denervated rat muscle. Rev Bras Fisioter. 2008;12(2):143-8.

21. Oliveira LS, Sobral LL, Takeda SYM, Betini J, Guirro RRJ, Somazz MC, et al. Estimulación eléctrica y natación en la fase aguda de la axonotmesis: influencia sobre la regeneración nerviosa y la recuperación funcional. Rev Neurol. 2008;47(1):11-5

22. Holcomb W, Rubley MD, Girouard TJ. Effect of the simultaneous application of NMES and HVPC on knee extension torque. J Sport Rehabil. 2007;16(4):307-18

23. Bettany JA, Fish DR, Mendel FC. Influence of high voltage pulsed direct current on edema formation following impact injury. Phys Ther. 1990;70(4):219-24.

24. Baker LL, Chambers R, DeMuth SK, Villar F. Effects of electrical stimulation on wound healing in patients with diabetic ulcers. Diabetes Care. 1997;20(3):405-12.

25. Houghton PE, Kincaid CB, Lovell M, Campbell KE, Keast DH, Woodbury MG, et al. Effect of electrical stimulation on chronic leg ulcer size and appearance. Phys Ther. 2003;83(1):17-28.

26. Mohr T, Akers T, Wessman HC. Effect of high voltage stimulation on blood flow in the rat hind limb. Phys Ther. 1987;67(4):526-33

27. Griffin JW, Newsome LS, Stralka SW, Wright PE. Reduction of chronic posttraumatic hand edema: a comparison of high voltage pulsed current, intermittent pneumatic compression, and placebo treatments. Phys Ther. 1990;70(5):279-86.

28. Mira JC. Quantitative studies of the regeneration of rat myelinated nerve fibres: variations in the number and size of regenerating fibres after repeated localized freezings. J Anat. 1979;129(Pt1):77-93

29. Orida N, Feldman JD. Directional protrusive pseudopodial activity and motility in macrophages induced by extracellular electric fields. Cell Motil. 1982;2(3):243-56.

30. Furuno K, Goodman MN, Goldberg AL. Role of different proteolytic systems in the degradation of muscle proteins during denervation atrophy. J Biol Chem. 1990;265(15):8550-7.

31. Carter AJ, Kristmundsdottir F, Gilmour J, Glasby MA. Changes in muscle cytoarchitecture after peripheral nerve injury and repair. A quantitative and qualitative study. J Hand Surg $\mathrm{Br}$. 1998;23(3):365-9 